Jurnal Ilmu-Ilmu Peternakan 26 (3): 79 - 90

ISSN : 0852-3681

E-ISSN : 2443-0765

CFakultas Peternakan UB, http://jiip.ub.ac.id/

\title{
Peranan kelompok peternak sapi potong Satwa Mulya terhadap keberdayaan rumah tangga peternak di Desa Brajan, Kecamatan Mojosongo, Kabupaten Boyolali Jawa Tengah
}

\author{
Abdul Lathif Apriyanto, Irdaf dan Anie Eka Kusumastuti \\ Fakultas Peternakan Universitas Brawijaya, Malang \\ Jl. Veteran Malang 65145 Jawa Timur \\ abdullathifapriyanto@gmail.com
}

\begin{abstract}
The purpose of this research were to describe: (1) the implementation of farmers group's activities in increasing the production of beef cattle, (2) the success of farmers group's activities in increasing the production of beef cattle and, (3) the success of the farmers group's role in empowering the farmers. The method of this research was a descriptive with qualitative model. The subject was officers of Satwa Mulya and citizen of Brajan Village. The research data were collected by using the method of participation and observation, interview, and documentation. The researcher wasthe main instrument which assisted with guidelines for observation, interview, and documentation.Method in this research were used data display, data reduction, and conclusion drawing.The results showed that: (1) The existence of farmers groups can increase the farmers knowledge in managing the beef cattle business started from seed selection, feeding, maintenance and marketing. In addition, also be increased the motivation and solidarity of farmers within the group. (2) While the implementation of farmers group's activities in increasing the beef cattle production is good enough which includes: awarding the concentrates weighing livestock from government, artificial insemination, supplementation and pregnancy checking. (3) Furthermore the success of the farmers group's role in communitiesproductivity can be seen from the increasing prosperity of farmers in Brajan village.So, it can be concluded that existence of farmers group's can increase the knowlegde of farmers especially about beef cattle production, their motivation and unity or farmers in its group.
\end{abstract}

Keywords: farmers group, productivity, beef cattle

\section{PENDAHULUAN}

Pembangunan desa memegang peranan yang penting karena merupakan bagian yang tidak terpisahkan dan pada hakikatnya bersinergi dengan pembangunan daerah dan nasional. Hal tersebut terlihat melalui banyaknya program pembangunan yang dirancang pemerintah untuk pembangunan desa. Bahkan hampir seluruh instansi pemerintah dae- rah mengakomodir pembangunan desa dalam program kerjanya. Tentunya berlandaskan pemahaman bahwa desa sebagai kesatuan geografis yang merupakan tempat bermukim sebagaian besar penduduk. Dalam struktur pemerintahan, desa menempati posisi terendah, tetapi merupakan garda terdepan dan langsung berada di tengah masyarakat sehingga dapat dipastikan apapun pro- 
gram pembangunanakan selalu bermuara ke desa.

Desa Brajan, Kecamatan Mojosongo, Kabupaten Boyolali masih memiliki berbagai permasalahan, seperti masih terisolir dari pusat-pusat pembangunan, terbatasnya prasarana sosial ekonomi serta penyebaran angkatan kerja produktif yang tidak seimbang, termasuk tingkat produktivitas, tingkat pendapatan masyarakat dan tingkat pendidikan yang relatif masih rendah. Semuanya itu pada akhirnya berkontribusi pada kemiskinan penduduk.

Seperti yang kita ketahui, masyarakat pedesaan banyak yang bermata pencaharian sebagai petani serta mempunyai usaha ternak seadanya seperti sapi dan kerbau yang dapat digunakan tenaganya untuk membajak sawah. Kondisi peternakanpun saat ini sebagian besar masih merupakan peternakan rakyat, dengan ciri-ciri diantaranya skala kepemilikan ternaknya yang relatif kecil atau sedikit berkisar 1-4 ekor ternak, penggunaan input teknologi dan inovasi yang relatif terbatas, serta mengandalkan kebutuhan pakan, khususnya untuk ternak ruminansia yaitu pada penyediaan hijauan yang sifatnya hanya cukup untuk sehari (cut and carry) (Mauludin dkk., 2012).

Pengembangan ternak sapi tentunya tidak terlepas dari peranan kelompok peternak dalam mengupayakan ternaknya agar mendapat nilai tambah serta efisien dalam pengelolaannya. Upaya yang perlu dikembangkan dalam membina dan memantapkan kelompok peternak adalah memperkuat kelembagaan ekonomi petani peternak di pedesaan. Sehingga perlu pendekatan yang efektif agar petani/peternak dapat memanfaatkan program pembangunan yang ada, secara berkelanjutan, melalui penumbuhan rasa memiliki, partisipasi dan pengembangan kreatifitas, disertai dukungan masyarakat lainnya sehingga dapat berkembang dan dikembangkan oleh masyarakat tani disekitarnya (Muslim, 2006). Melalui kelompok peternak sapi diharapkan para peternak dapat saling berinteraksi, sehingga mempunyai dampak saling membutuhkan, saling meningkatkan, saling memperkuat, sehingga akan meningkatkan pengetahuan dan kemampuan dalam mengelola sistem usaha peternakan sapi.

Salah satu strategi yang dapat didayagunakan di dalam meningkatkan kualitas peternak sehingga memiliki keberdayaan adalah peningkatan peran kelompok peternak. Sampai saat ini kelompok peternak masih digunakan sebagai pendekatan utama dalam kegiatan penyuluhan (Deptan, 2009). Pendekatan kelompok dipandang lebih efisien dan dapat menjadi media untuk terjadinya proses belajar (learning process) dan berinteraksi dengan para petani, sehingga diharapkan terjadi perubahan perilaku petani ke arah yang lebih baik atau berkualitas (Margono, 2001).

Keberdayaan merupakan dampak yang muncul dari proses pemberdayaan yang telah dilalui oleh seseorang seperti, peningkatan taraf hidup ke arah positif, pengembangan hasil belajar pada lingkungan sekitarnya dan berperan serta dalam pembangunan masyarakat (Suartha, 2013). Pemberdayaan suatu proses yang berjalan terus-menerus untuk meningkatkan kemampuan dan kemandirian masyarakat. Upaya itu hanya bisa dilakukan dengan membangkitkan keberdayaan untuk memperbaiki kehidupan di atas kekuatan sendiri. Asumsi dasar yang dipergunakan adalah bahwa setiap manusia mempunyai potensi dan daya untuk mengembangkan dirinya menjadi lebih baik. Pada dasarnya manusia bersifat aktif dalam upaya peningkatan keberdayaan dirinya. Dalam pemberdayaan upaya yang pokok adalah peningkatan taraf pendidikan dan derajat kesehatan serta akses dalam ke- 
mampuan sumber ekonomi seperti modal, keterampilan, teknologi, informasi dan lapangan kerja, pemberdayaan ini menyangkut pembangunan sarana dan prasarana dasar, baik fisik maupun non fisik.

Kabupaten Boyolali merupakan salah satu wilayah pengembangan sapi dengan populasi sebesar 150.024 ekor pada tahun 2013. Kabupaten Boyolali memiliki 19 kecamatan, salah satunya adalah Kecamatan Mojosongo yang merupakan urutan ketiga wilayah pengembangan sapi dengan populasi sebesar 14.512 ekor $(9,75 \%)$ setelah Kecamatan Musuk populasi sapi 27.815 ekor $(18,54 \%)$ dan Kecamatan Cepogo populasi sapi 16.276 ekor $(10,84 \%)$ dari total keseluruhan populasi sapi di Kabupaten Boyolali. Desa Brajan hanya memiliki satu kelompok peternak sapi potong dan baru terbentuk sekitar kurang lebih 2 tahun, sehingga belum pernah ada penelitian tentang kelompok peternak sapi potong tersebut. Oleh karena itu perlu dilakukan penelitian tentang peranan kelompok peternak sapi potong Satwa Mulya terhadap keberdayaan rumah tangga peternak di Desa Brajan, Kecamatan Mojosongo, Kabupaten Boyolali Jawa Tengah

\section{MATERI DAN METODE}

Penelitian ini dilakukan Desa Brajan, Kecamatan Mojosongo, Kabupaten Boyolali Jawa Tengah pada tanggal 17 Juni sampai 17 Juli 2016. Metode penelitian menggunakan pendekatan kualitatif, yakni mengamati orang dalam lingkungannya berinteraksi dengan mereka, berusaha memahami bahasa dan tafsiran mereka tentang dunia sekitarnya (Sugiyono, 2015). Pada penelitian kualitatif, subyek sumber data menggunakan perspektif emic, artinya mementingkan pandangan informan, yakni bagaimana mereka memandang dan menafsirkan dunia dari pendiriannya. Pengambilan data dengan mengikuti aktivitas peternak dan observasi serta melakukan wawancara (indepth interview) mendalam kepada informan. Data dianalisis secara deskriptif mengikuti konsep Susanti (2013) mengemukakan bahwa aktivitas dalam analisis data kualitatif dilakukan secara interaktif dan berlangsung secara terusmenerus pada setiap tahapan penelitian sampai tuntas dan datanya jenuh. Aktivitas tersebut adalah data reduksi (data reduction), penyajian data (data display), dan conclusion drawing atau verification.

\section{HASIL DAN PEMBAHASAN}

Kabupaten Boyolali terkenal dengan usaha pengembangan sapi perah dan penggemukan sapi. Kabupaten Boyolali termasuk wilayah pegunungan, hal ini menyebabkan iklim yang dingin sehingga memungkinkan pemeliharaan sapi perah. Kabupaten Boyolali dijuluki dengan kota susu karena termasuk sebagai penghasil susu terbanyak di Jawa Tengah dan kabupaten ini memiliki landmark sapi perah yang melambangkan banyaknya sapi perah di Kabupaten Boyolali.

Desa Brajan merupakan salah satu desa yang terletak di Kabupaten Boyolali. Desa Brajan memiliki luas wilayah 298,77 Ha yang memiliki ketinggian 700 meter di atas permukaan laut yang termasuk dalam wilayah lereng Gunung Merapi bagian Timur. Desa Brajan dialiri sungai yang rata-rata mempunyai terbing terjalan, terdapat material vulkanik berukuran halus sampai bongkahan yang terdiri dari batuan beku hasil erupsi gunung berapi. Topografi berpengaruh terhadap kemampuan produktifitas sapi potong, dengan ketinggian 700-1250 meter dpl sapi po- 
tong dapat mengalami pertumbuhan bobot badan yang tinggi.

Desa Brajan termasuk tanah agroekosistem yang mempunyai ciri-ciri berbutir kasar, kaya unsur hara sehingga bersifat subur, $\mathrm{pH}$ berkisar antara 6-7, cenderung gembur kemampuan menyerap air tinggi, dan bewarna kelabu hingga kuning, sehingga baik dimanfaatkan sebagai pertanian padi, palawijaya, tebu, dan kelapa. Jenis tanah yang subur dapat menyediakan pakan hijauan yang melimpah, sehingga usaha ternak sapi potong dapat berkembang dengan baik.

Desa Brajan terdapat empat sungai sebagai penyedia air baku yaitu Sungai Serang, Cemoro, Pepe dan Gandul. Sumber air tersebut dapat menunjang kegiatan pengelolaan lahan sawah yang sangat membutuhkan pengairan terutama untuk menanam padi sawah dan tanaman palawija serta juga terdapat sumber air dangkal/mata air.Suhu maksimum Desa Brajan Kecamatan Mojosongo sekitar $32^{\circ} \mathrm{C}$ dan suhu minimumnya sekitar $18^{\circ} \mathrm{C}$, sedangkan suhu rata-rata per tahun sebesar $25^{\circ} \mathrm{C}$. Desa Brajan Kecamatan Mojosongo memiliki kurang lebih 72 hari hujan dengan curah rata-rata sebesar 2.478 $\mathrm{mm}$ per tahunnya. Usaha sapi potong baik di budidayakan pada tempat yang bersuhu antara $17^{\circ} \mathrm{C}-27^{\circ} \mathrm{C}$, dengan suhu rata-rata pertahun sebesar $25^{\circ} \mathrm{C}$ maka usaha penggemukan sapi potong dapat tumbuh dengan baik di Desa Brajan.

\section{Mata pencaharian penduduk}

Mata pencaharian penduduk Desa Brajan secara keseluruhan cukup beragam mulai dari sektor pertanian (petani dan peternak) sampai sektor non pertanian. Adapun mata pencaharian penduduk dapat dilihat dalam Tabel 1.

Tabel 1. Mata pencaharian utama penduduk Desa Brajan

\begin{tabular}{lll}
\hline Pekerjaan/Mata Pencaharian Utama & Jumlah (Jiwa) & Presentase (\%) \\
\hline Petani & 1067 & 55,26 \\
Peternak & 569 & 29,45 \\
Usaha Kecil & 39 & 2,02 \\
Buruh Industri & 105 & 5,44 \\
Buruh Bangunan & 121 & 6,27 \\
Supir & 10 & 0,52 \\
PNS/TNI & 20 & 1,03 \\
\hline Total & 1931 & 100 \\
\hline
\end{tabular}

Sumber: Monografi Desa Brajan (2015)

Berdasarkan Tabel 1, dapat diketahui status pekerjaan mendominasi sektor informal $93,53 \%$ pekerjaan ini tidak ada jaminan sosial dan kelanjutan pekerjaanya tidak menentu dan sisanya di sektor formal. Penduduk yang bermata pencaharian di sektor pertanian sangat banyak dengan presentase $84,74 \%$ sementara sisanya pada sektor non pertanian dengan presentase $15,26 \%$. Hal tersebut dikarenakan lapangan pekerjan yang langka di pedesaan maka banyak penduduk yang menggantungkan hidup dengan memelihara ternak dan bertani. Jumlah peternak di Desa Brajan cukup besar karena faktor dari sumber daya alam (SDA) seperti banyaknya hijauan serta iklim dan cuaca yang sangat cocok untuk kegiatan beternak. 


\section{Organisasi kelompok peternak sapi Satwa Mulya}

Desa Brajan memiliki 2 kelompok peternak yaitu kelompok peternak sapi perah Sumber Makmur dan kelompok peternak sapi potong Satwa Mulya. Kelompok peternak sapi perah Sumber Makmur merupakan kelompok peternak yang sudah lama di Desa Brajan, namun kelompok peternak sapi perah Sumber Makmur sudah tidak aktif dikarenakan para anggotanya yang sudah tua dan tidak ada penerusnya. Kelompok peternak sapi Satwa Mulya berdiri 20 Januari 2014 yang merupakan organisasi masyarakat peternak yang menyelenggarakan kegiatan di bidang ternak sapi potong. Anggota kelompok peternak Sat- wa Mulya terdiri dari 23 peternak muda yang bergabung menjadi satu. Setiap peternak yang tergabung dalam kelompok peternak dapat mengakses segala bentuk bantuan dan mengikuti aktivitas yang dilaksanakan oleh kelompok peternak.

\section{Profil anggota kelompok peternak}

Profil anggota kelompok peternak Satwa Mulya yang terdiri dari umur dan tingkat pendidikan. Produktivitas manusia dipengaruhi oleh umur, karena pada umur produktif manusia dalam kondisi prima serta semangat yang memuncak. Lebih jelasnya dapat dilihat pada Tabel 2.

Tabel 2. Umur anggota kelompok peternak

\begin{tabular}{|c|c|c|}
\hline Umur (tahun) & Peternak (jiwa) & Presentase $(\%)$ \\
\hline $35-39$ & 4 & 17,40 \\
\hline $40-44$ & 4 & 17,40 \\
\hline $45-49$ & 3 & 13,04 \\
\hline $50-54$ & 8 & 34,78 \\
\hline $55+$ & 4 & 17,40 \\
\hline Jumlah & 23 & 100 \\
\hline
\end{tabular}

Sumber: Data primer diolah (2016)

Berdasarkan Tabel 2 dapat dilihat bahwa umur peternak berkisar 35$55+$ tahun, yang terdiri dari 11 peternak yang dibawah 50 tahun dan yang diatas 50 tahun terdapat 12 peternak, dengan demikian hampir keseluruhan anggota kelompok peternak berusia produktif yang aktif dalam usaha penggemukan sapi potong akan berpengaruh terhadap pengembangan sapi potong karena dipengaruhi kekuatan fisik yang prima dan semangat yang memuncak. Menurut BPS (2016) usia produktif berkisar antara 15-64 tahun. Pada saat usia produktif manusia menjadi lebih disiplin serta fisik yang prima sehingga tidak mudah sakit. Pendidikan sangat penting, karena dari proses pendidikan kita dapat membedakan bagaimana caranya bersikap, mengatasi masalah dan berintelektual. Lebih jelasnya dapat dilihat pada Tabel 3.

Tabel 3. Tingkat pendidikan anggota kelompok peternak

\begin{tabular}{lcc}
\multicolumn{1}{c}{ Tingkat pendidikan } & Peternak (jiwa) & Presentase $(\%)$ \\
\hline SMA & 16 & 69,56 \\
SMK & 7 & 30,43 \\
\hline Jumlah & 23 & 100 \\
\hline
\end{tabular}


Berdasarkan Tabel 3 pendidikan anggota dapat dikatakan cukup tinggi, karena tidak satupun yang berpendidikan rendah tetapi keseluruhanya berpendidikan SLTA terutama SMK dan SMA. Pendidikan berkaitan dengan kemampuan seseorang dalam memahami sesuatu, makin tinggi pendidikan cenderung akan lebih banyak input dalam pemikirannya, dengan memiliki pendidikan formal lebih tinggi akan memiliki motivasi yang tinggi dan wawasan yang luas dalam menganalisis sesuatu kejadian, sehingga orang yang berpendidikan akan mudah menerima inovasi. Sesuai dengan pernyataan Ningsih (2013) bahwa seseorang yang memiliki pendidikan cukup tinggi dapat mengatasi kendala yang dihadapi, ke- mampuan manajemen, serta pengalaman dalam sebuah organisasi sangat mempengaruhi proses penyerapan informasi akan inovasi dan penerapan teknologi yang ada dilingkungan mereka.

\section{Profil usaha anggota kelompok pe- ternak}

Berikut ini merupakan profil usaha kelompok peternak Satwa Mulya yang terdiri dari kepemilikan sapi, jumlah keluarga, bangsa sapi yang dipelihara dan umur sapi yang dipelihara. Kepemilikan sapi merupakan modal dalam suatu usaha peternakan yang akan menentukan pendapatan peternak. Lebih jelasnya dapat dilhat pada Tabel 4 .

Tabel 4. Kepemilikan sapi

\begin{tabular}{lcc}
\hline Kepemilikan sapi (ekor) & Peternak (jiwa) & Presentase $(\%)$ \\
\hline 1 & 13 & 56,52 \\
2 & 5 & 21,74 \\
3 & 3 & 13,04 \\
4 & 1 & 4,35 \\
5 & 1 & 4,35 \\
\hline Jumlah & 23 & 100 \\
\hline
\end{tabular}

Sumber: Data primer diolah (2016)

Berdasarkan Tabel 4 dapat dilihat kepemilikan sapi anggota kelompok peternak berkisar 1-5 ekor, yang didominasi jumlah kepemilikan 1-2 ekor sapi yaitu 19 peternak $(82,6 \%)$. Hal tersebut dikarenakan keterbatasan modal peternak untuk meningkatkan jumlah kepemilikan sapi potong, serta kurangnya pengetahuan peternak terhadap manajemen dan teknologi.Selain itu juga peternak masih mempertimbangkan beban biaya pemeliharaan apabila jumlah ternak yang dimiliki melebihi kemam- puan manajemen peternak sehingga dapat dikatakan peternak rakyat berskala kecil. Berdasarkan pendapat Siregar (2013) bahwa keterbatasan kepemilikan ternak yang ada pada peternakan sapi rakyat mengakibatkan pendapatan yang diterima peternak rendah sehingga tidak mampu dijadikan sebagai sumber penghasilan utama. Jumlah anggota keluarga sangat menentukan kesejahteraan peternak, karena menjadi suatu tanggungan kepala keluarga. Lebih jelasnya dapat dilihat pada Tabel 5. 
Tabel 5. Jumlah anggota keluarga yang menjadi tanggungan peternak

\begin{tabular}{lcc}
\hline Anggota Keluarga & Peternak (jiwa) & Presentase $(\%)$ \\
\hline $1-3$ & 6 & 26,09 \\
$4-6$ & 15 & 65,22 \\
$7-9$ & 2 & 8,69 \\
\hline Jumlah & 23 & 100 \\
\hline
\end{tabular}

Sumber: Data Primer diolah (2016)

Dapat dilihat pada Tabel 5 anggota keluarga anggota kelompok peternak berkisar 1-9 orang dan ada 15 peternak $(65,22 \%)$ yang memiliki tanggungan dalam menghidupi 4-6 orang. Jumlah anggota keluarga akan menentukan besarnya tanggungan kepala keluarga untuk pemenuhan kebutuhan hidup. Semakin besar anggota keluarga, maka semakin besar juga kebutuhan hidup seperti kebutuhan makanan dan non makanan. Hal tersebut yang akan menentukan tingkat kesejahteraan rumah tangga. Sesuai dengan pendapat Purba (2008) bahwa faktor yang mempengaruhi tingkat kesejahteraan rumah tangga pedesaan adalah tingkat penda- patan dan tingginya pengeluaran untuk konsumsi rumah tangga.

Beternak sapi bukan sebagai pendapatan yang utama, tetapi hanya sebagai pendapatan sampingan. Meskipun anggota keluarga yang menjadi tanggungan tidak terlalu besar berkisar 4-6 anggota keluarga yang terdiri dari orang tua, ayah, ibu, anak dan ponakan yang tinggal bersama, tetapi tetap membutuhkan tabungan masa depan yang sewaktu-waktu dapat dijual. Sementara untuk bangsa sapi yang dipelihara anggota kelompok peternak menentukan besarnya pendapatan peternak, karena pertambahan bobot badan sapi potong sangat menentukan kualitas. Lebih jelasnya dapat dilihat pada Tabel 6

Tabel 6. Bangsa sapi yang dipelihara

\begin{tabular}{lcc}
\multicolumn{1}{c}{ Bangsa sapi } & Jumlah sapi (ekor) & Presentase (\%) \\
\hline Cross breed Limosin & 16 & 39,02 \\
Cross breed Simental & 25 & 60,97 \\
\hline Jumlah & 41 & 100 \\
\hline
\end{tabular}

Sumber: Data Primer diolah (2016)

Berdasarkan pada Tabel 6 dapat diketahui bangsa sapi untuk penggemukan yang dipelihara peternak yaitu sapi Cross breed Limosin dan Cross breed Simental termasuk bangsa sapi unggul. Peternak memilih bangsa sapi tersebut atas pembinaan dari kelompok peternak serta bangsa sapi tersebut mampu memiliki pertumbuhan badan yang cepat dan juga lebih tahan terhadap serangan berbagai macam penyakit dibandingkan dengan sapi lokal seperti PO, dengan demikian pengetahuan peternak sema-

kin meningkat setelah tergabung kedalam kelompok peternak. Soeharsono (2010) sapi impor dan turunannya memiliki ADG (Average daily again) sebesar $1,62 \mathrm{~kg} / \mathrm{hari}$ lebih tinggi bila dibandingkan dengan sapi potong lokal hasil inseminasi buatan yang hanya mencapai 1,42 kg/hari. Umur dalam penggemukan sapi potong perlu diperhatikan, karena dalam umur tertentu pertumbuhan sapi potong dapat optimal. Lebih jelasnya dapat dilihat pada Tabel 7. 
Tabel 7. Umur sapi pada awal penggemukan

\begin{tabular}{cccc}
\hline Umur sapi (tahun) & Jumlah sapi (ekor) & $\begin{array}{c}\text { Satuan ternak } \\
(\mathrm{ST})\end{array}$ & Presentase (\%) \\
\hline 2 & 15 & 0,5 & 36,59 \\
2,5 & 18 & 0,5 & 43,91 \\
3 & 7 & 1 & 17,04 \\
3,5 & 0 & 1 & 0 \\
4 & 1 & 1 & 2,45 \\
\hline Jumlah & 41 & 4 & 100
\end{tabular}

Sumber: Data Primer diolah (2016)

Berdasarkan pada Tabel 7 dapat dilihat umur sapi yang dipelihara anggota kelompok peternak yaitu 2-3 tahun dan hanya 1 orang saja yang memelihara sapi potong berumur 3 tahun. Alasan peternak memelihara sapi pada umur 23 tahun karena sapi tergolong fase produktifitas pertumbuhan dan efisiensi penggunaan pakannya pun cukup tinggi, dengan demikian anggota sudah dapat memilih umur ternak yang optimal dalam penggemukan. Hal ini sesuai dengan pernyataan Mauludin dkk. (2012) secara teoritis umur sapi bakalan yang baik untuk digemukan adalah 1,5-2,5 tahun atau gigi seri tetap sudah 1-2 pasang (poel 1 dan 2) karena umumnya sapi bakalan yang berumur demikian memiliki laju pertumbuhan yang optimal dan efisiensi pakan yang tinggi.

\section{Aktivitas yang telah dilaksanakan kelompok peternak Satwa Mulya}

Aktivitas yang telah dilaksanakan kelompok peternak adalah pertemuan rutin dilakukan setiap bulan pada minggu kedua, arisan, pengecekan kebuntingan dan pemberian suplemen dilakukan setiap 4 bulan sekali pada ternak sapi, inseminasi buatan, penanaman hijaun pakan ternak, penimbangan sapi potong untuk mengetahui pertambahan bobot badan setiap bulan dan pendistribusian konsentrat keseluruh anggota kelompok. Peran dan fungsi kelompok peternak yaitu sebagai penyedia input sapronak, dapat membantu penyediaan modal, wadah kerjasama dan penyedia informasi serta pemasaran yang secara kolektif agar peternak tidak dirugikan para makelar.

Aktivitas yang dilaksanakan kelompok peternak merupakan bagian dari suatu usaha untuk kemandirian suatu kelompok dan perlu pembinaan sebagai pedoman agar tidak ada kesalahan dalam suatu kegiatan. Sebagaimana pendapat Soedarmanto (2003) bahwa pembinaan kelembagaan peternak dilaksanakan secara komprehensif, meliputi kegiatan pembinaan kelompok peternak yang diarahkan untuk memberdayakan peternak agar memiliki kekuatan mandiri yang mampu menerapkan inovasi (teknis, sosial, ekonomi), mampu memanfaatkan azas skala ekonomi dan mampu menghadapi resiko usaha, sehingga mampu memperoleh tingkat pendapatan yang layak. Oleh karena itu pembinaan diarahkan agar kelompok peternak dapat berfungsi sebagai wadah proses belajar-mengajar, sebagai unit produksi, dan sebagai wahana kerjasama menuju kelompok peternak sebagai kelompok usaha. Sebagai kelas belajar mengajar yaitu kelompok peternak merupakan wadah bagi anggotanya untuk berinteraksi guna meningkatkan pengetahuan, keterampilan dan sikap (PKS) dalam mengembangkan usaha sapi potong yang lebih baik dan lebih menguntungkan serta mandiri untuk mencapai kehidupan yang lebih baik sejahtera. 


\section{Keberdayaan peternak setelah menjadi anggota kelompok}

Motivasi untuk maju tampak dapat ditunjukan dari kehadiran mengikuti pertemuan kelompok, mengadopsi teknologi yang disalurkan ketua kelompok, sering mendiskusikan hal-hal terkait dengan teknologi dan masalah-masalah teknis yang dihadapi. Tidak hanya dengan ketua tetapi juga dengan anggota kelompok yang sudah lebih maju, dengan kata lain peternak ingin berubah dalam tatacara beternak tradisional kearah yang lebih baik dengan menerapkan teknologi yang diperoleh selama menjadi anggota kelompok peternak

Pemilihan bibit sebelum tergabung dengan kelompok peternak, peternak cenderung memilih sapi peranakan ongole (PO) karena pada saat itu peternak hanya melihat dari segi harganya saja. Namun setelah masuk sebagai anggota kelompok peternak dan mengikuti aktivitasnya, peternak sudah bisa memilih dan menentukan sendiri bibit sapi bakalan yang baik mulai dari melihat bangsa dan sifat genetiknya, yaitu dengan memilih sapi potong jenis Cross breed Limosin dan Cross breed Simental karena pertambahan bobot badan perharinya lebih bagus dari pada sapi potong jenis PO, selain itu peternak juga diajarkan pengamatan fisik calon bibit sapi potong yang baik yaitu dilihat dari ukuran badan panjang dan dalam serta rusuk tumbuh panjang yang memungkinkan sapi mampu menampung jumlah makanan yang banyak, bentuk tubuh segi empat, pertumbuhan tubuh bagian depan, tengah dan belakang serasi, garis badan atas dan bawah sejajar, paha sampai pergelangan penuh berisi daging, dada lebar dan dalam serta menonjol ke depan serta kaki besar dan kokoh.

Lahan pertanian di Desa Brajan ditanami hijauan rumput gajah, sehing- ga sehari-hari peternak hanya memberikan pakan hijauan untuk ternak secara terus menerus dan tanpa takaran pasti, namun bergabung dengan kelompok, peternak diajarkan bahwa hijauan saja tidak cukup dan harus ada pakan tambahan bekatul untuk memenuhi kebutuhan gizi sapi potong, sehingga pertambahan bobot badan sapi dapat maksimal. Pakan hijaun rumput gajah dicacah terlebih dahulu menggunakan copper agar sapi tidak memilih pakan serta mudah dikunyah dan pakan tambahan bekatul dimasak terlebih dahulu agar mudah dicerna. Pakan hijauan rumput gajah segar yang diberikan ke sapi potong sebesar 10\% hijauan dari bobot badan sapi potong, sementara pakan tambahan bekatul dalam bentuk bahan kering sebesar $2 \%$ dari bobot badan sapi potong yang diberikan pada pagi dan sore hari.

Sebelum bergabung dengan kelompok peternak, kesehatan sapi potong kurang diperhatikan dan tidak pernah diberikan suplemen pada sapi potong, Namun setelah menjadi anggota kelompok peternak dan mengikuti aktivitasnya, peternak sudah dapat mengetahui akan pentingnya suplemen atau obatobatan untuk memenuhi nutrisi yang kurang dan untuk pertambahan bobot badan. Salah satu aktivitas kelompok peternak untuk menjaga kesehatan serta meningkatkan nafsu makan sapi potong yaitu dengan pemberian suplemen.

Peternak dulu memelihara sapi potong dekat dengan dapur serta tidak ada atap untuk melindungi sapi dari hujan atau terik matahari dan apabila peternak masak, asapnya mengenai sapi potong sehingga mengganggu kesehatan dan kenyamanan sapi potong.Namun sistem perkandangan sapi potong saat ini sudah sangat diperhatikan karena kandang berfungsi untuk melindungi sapi potong dari terik matahari dan hujan, sehingga sapi potong dapat beristi- 
rahat dengan nyaman serta memudahkan pelaksanaan pemeliharaan.

Pemilihan lokasi kandang juga harus diperhatikan seperti harus dekat pembuangan limbah, tersedia air bersih yang cukup dan lantai kandang dibuat agak miring agar lebih mudah membersihkan kotoran. Selain itu sistem pemeliharaan juga penting agar mendapat hasil yang maksimal. Pemeliharaan pada saat ini sapi potong dimandikan agar lebih sehat dan menghilangkan bibit penyakit yang menempel pada sapi potong. Sapi potong juga dijemur pada pagi hari karena sinar matahari pagi mengandung vitamin $\mathrm{D}$ yang bermanfaat terhadap struktur tulang dan meningkatkan daya tahan tubuh. Sinar matahari juga bisa membunuh virus dan jamur yang bersarang. Berbeda dengan sistem pemeliharaan terdahulu jarang sekali bahkan tidak pernah sapi potong dimandikan ataupun dijemur dan hanya sekedar memberi pakan saja.

Peternak dulu menjual sendiri sapinya di pasar ternak bukan berdasarkan berat ternak tetapi berdasarkan perkiraan sehingga peternak merasa dirugikan, karena pada saat penentuan harga dengan melakukan bisik-bisik agar tidak terdengar dengan pedagang lain sehingga penjualan sapi potong tidak transparan, pada saat ini peternak yang ingin menjual sapi potongnya bisa meminta bantuan pada bagian pemasaran dan karena kelompok peternak sudah punya timbangan, maka sapi potong ditimbang dahulu sebelum menentukan harga sehingga penjualan lebih terbuka dan transparan serta peternak tidak perlu khawatir dirugikan. Peternak juga dapat menjual sapi potongnya secara kolektif yaitu pada saat moment tertentu seperti Idul Adha dan Idul Fitri, selain itu dapat menghemat biaya transportasi, karena untuk biaya penyewaan truk dapat ditanggung bersama.
Sebelum tergabung kelompok, peternak tidak dapat menabung karena untuk memenuhi kebutuhan sehari-hari saja masih kurang, sehingga sering meminjam uang pada rentenir. Setelah tergabung kelompok peternak menjadi semakin baik, kondisi keberdayaan mereka semakin meningkat terlihat dari tinggkat pendapatan dan kehidupanya semakin bertambah karena produksi sapi potong mereka meningkat. Selain itu, masyarakat peternak dapat terpenuhi kebutuhan sehari-harinya (kebutuhan primer) dan mampu mengatasi masalahmasalah yang mereka hadapi pada waktu masa pemeliharaan sampai pada masa penjualan dengan bantuan kelompok peternak.

Pembentukan kelompok merupakan sarana interaksi sosial dan untuk saling mengenal satu sama lain sehingga menjadi lebih akrab. Dengan berinteraksi sosial tidak hanya untuk memperkuat ikatan hubungan saja, tetapi mereka dapat bercerita tentang masalah serta solusi untuk menghadapi masalah tersebut dan merasa bangga menjadi bagian dari kelompok yang dapat ditunjukan dengan memakai baju kelompok peternak sapi Satwa Mulya yang berlogo kepala sapi. Peternak memakai baju kelompok tidak hanya untuk pertemuan dan kegiatan kelompok saja, tetapi pada saat ke pasar atau ke tempat lainnya pun suka mengenakan baju kelompok. Anggota kelompok juga sering bercerita ke peternak lain tentang keberhasilan kelompoknya seperti tingginya pertambahan bobot badan sapi, tingginya harga jual sapi mereka dan juga memasang kalender di dinding ruang tamu mereka, karena ruang tamu merupakan ruangan kebanggaan pada setiap rumah. Peternak juga sangat rajin mengikuti setiap aktivitas yang dilakukan kelompok, meskipun jarak antara rumah dan kegiatan cukup jauh. 


\section{KESIMPULAN}

Berdasarkan hasil penelitian dan pembahasan, maka dapat ditarikkesimpulan sebagai berikut:

1. Keberadaan kelompok peternak dapat meningkatkan pengetahuan peternak tentang pengelolaan usaha peternakan sapi potong mulai dari hulu sampai hilir sehingga dapat meningkatkan produksi. Selain itu dapat meningkatkan motivasi dan meningkatkan solidaritas (kebersamaan) peternak dalam kelompok.

2. Motivasi untuk maju tampak dapat ditunjukan dari kehadiran mengikuti pertemuan kelompok, mengadopsi teknologi yang disalurkan ketua kelompok, sering mendiskusikan halhal terkait dengan teknologi dan masalah-masalah teknis yang dihadapi. Tidak hanya dengan ketua tetapi juga dengan anggota kelompok yang sudah lebih maju, dengan kata lain peternak ingin berubah dalam tatacara beternak tradisional kearah yang lebih baik dengan menerapkan teknologi yang diperoleh selama menjadi anggota kelompok peternak.

3. Kelompok peternak dapat meningkatkan keberdayaan anggotanya karena banyak pengetahuan inovasiinovasi yang dapat diadopsi sehingga dapat diterapkan dalam aktivitas penggemukan sapi potong, serta pada giliranya dapat meningkatkan kinerja dan produktivitas sapi potong.

\section{DAFTAR PUSTAKA}

Conyers, D. 1991. Perencanaan Sosial di Dunia Ketiga. Yogyakarta: Gadjah Mada University Press.

Fahrudin, A. 2012. Pemberdayaan Partisipasi dan Penguatan Kapasitas Masyarakat. Humaniora Bandung. Bandung.

Korten, C., dan Sjahrir. 1988. Pembangunan Berdimensi Kerakyatan.
Jakarta: Yayaysan Obor Indonesia.

Margono, S. 2001. Paradigma Baru Penyuluhan Pertanian di Era Otonomi Daerah. Disajikan pada Seminar Perhiptani 2001. Tasikmalaya.

Mauludin, M.A., S, Winaryanto, dan S, Alim. 2012. Peran Kelompok dalam Mengembangkan Keberdayaan Peternak Sapi Potong (Kasus di Wilayah Selatan Kabupaten Tasikmalaya). Jurnal Ilmu Tenak, 12(1): $1-8$

Ningsih, D. L. 2013. Peran Kelembagaan Dalam Meningkatkan Kreativitas Dan Inovasi Petani Pada Integrated Farming System Di Gapoktan Silih Asih, Jawa Barat. Fakultas Ekonomi Dan Manajemen Institut Pertanian Bogor. Bogor

Saragih, B. 2004. Pertanian Mandiri: Membangun Pertanian Perspektif Agribisnis. Malang: UIN-Maliki press.

Siregar, N. W. P. 2013. Faktor-Faktor Yang Mempengaruhi Usaha Ternak Sapi Potong di Desa Mangkai Lama Kecamatan Lima Puluh Kabupaten Batubara Provinsi Sumatera Utara. Fakultas Ekonomi dan Manajemen Institut Pertanian Bogor. Bogor

Soedarmanto. 2003. Penyuluhan dan Komunikasi Pertanian. Fakultas Pertanian Universitas Brawijaya Malang. Malang

Soeharsono, R.A. Saptati dan K. Diyanto. 2010. Penggemukan Sapi Lokal Hasil Inseminasi Buatan dan Sapi Bakalan Impor dengan Menggunakan Bahan Pakan Lokal. Seminar Nasional Teknologi Peternakan dan Veteriner

Suartha, N. 2013. Pengaruh Kapasitas Rumah Tangga, Budaya dan Pemberdayaan Terhadap Sikap 
Serta Keberdayaan Rumah Tangga Miskin di Kabupaten Karangasem. Program pascasarjana Universitas Udayana Denpasar.Denpasar.
Sugiyono. 2015. Memahami penelitian kualitatif. Bandung: Alfabeta.

Susanti, E. 2013. Penelitian kualitatif. Eds Bagong Suyanto dan Sutinah. Metode penelitian sosial. Jakarta: Kencana. 